\title{
A Systematic Review of Employee Retention: What's Next in Pakistan?
}

\author{
Attia Aman-Ullah*, Azelin Aziz \& Hadziroh Ibrahim \\ School of Business Management, \\ University Utara Malaysia, Malaysia \\ Email:attiaamanullah@yahoo.com
}

DOI: https://doi.org/10.37134/jcit.vol10.sp.4.2020

Cite this paper (APA): Aman-Ullah, A., Aziz, A., \& Ibrahim, H. (2020). A Systematic Review of Employee Retention: What's Next in Pakistan?. Journal of Contemporary Issues and Thought, 10, 36-45. https://doi.org/10.37134/jcit.vol10.sp.4.2020

\begin{abstract}
The purpose of this paper is to review existing literature on the uncommon phenomenon of employee retention in the context of Pakistan. With that objective, this work utilizes literature on employee retention determinants. Based on the thorough literature review, it was found that human resource practices, motivation and compensation are the most highlighted factors in the banking, education and telecom sectors of Pakistan. In addition, the social exchange theory was found to be the most frequently used theory for explaining the phenomenon. Further exploration of employee retention is needed to better comprehend this concept in terms of industry, methodology and theory. For example, retail, manufacturing, hotels and healthcare sectors that have been neglected in past researches could be explored in future studies in Pakistan. Methodology wise, the application of the partial least square method could be a valuable addition to the new studies. Lastly, on the theoretical side, new theories other than the social exchange theory could be empirically incorporated such as the resource-based theory, knowledge base theory and dynamic capability theory which could provide a promising area of research.
\end{abstract}

Keywords: Employee Retention; Pakistan; Human Resource Practices

\section{Introduction}

Employee Retention is a combination of certain policies and procedures through which organizations can keep their talented employees for longer periods of time (Nasir et al., 2019). Therefore, it saves organisations from incurring unnecessary expenses while increasing their intellectual capabilities and improving competitive advantage. The retention of employees is found to be one of the greatest challenges of the twenty-first century which needs to be tackled carefully (Iqbal et al., 2017). Many employees are switching jobs and shifting to other countries, thus causing lower retention. Developing countries are the main victim of brain-drain and the most likely culprits are the push and pull factors (Najib et al., 2019). This solidifies the need to ensure employee retention in these countries.

Pakistan is one of the developing countries struggling with the problem of low employee retention (Ghulam et al., 2019). Many highly skilled individuals are leaving Pakistan every year to pursue careers abroad. According to the Bureau of Emigration \& Overseas Employment, approximately 10 million skilled Pakistanis are serving abroad. In the last two years, 884,000 people have left the country with 300,000 moving out in 2018 and 500,000 in 2019. The majority 
of them are reportedly doctors, engineers and accountants in search for a more stable future. When compared to neighboring countries like India and Bangladesh, Pakistan shows an increasing trend of immigration i.e., 15\% (Pakistan Bureau of Statistics, 2019). The country is experiencing an extreme shortage of skilled workers in every field, making it difficult to complete major projects, thus hindering the achievement of sustainable development goals and economic prosperity. Therefore, organizations are now more concerned about employee retention. Retaining existing employees helps organizations on many grounds such as preventing talent loss, monetary loss, reputation loss and relationship loss.

Over the period of one-decade, many researchers have contributed to the body of literature on retention and attempted to solve the never-ending problem of employee retention through various studies and suggestions. However, up until now, no literature reviews have been found in the context of Pakistan that could suggest future research avenues for the ongoing issue of low employee retention. Therefore, this study is an effort to review all existing literature on employee retention from Pakistan to identify what has been done and what could be suggested next. Additionally, this present study will also help to identify the sector with the most determinants and the sector which requires further studies because the impact of low retention is so vast that almost every organization whether public or private is affected. Based on the premise, most of all organizations are now confronted with the problem of low employee retention and high turnover across all sectors. This study aims to provide an overview of all the empirical literature in Pakistan that highlights the determinants of employee retention in all the industries in the country. The determinants as identified in the preceding literature are also investigated together with those that have yet been studied to determine the true cause of low employee retention in Pakistan. The present study is descriptive in nature and is based on secondary data collected from different journals and internet sources. It excludes conceptual studies and those with missing information such as those taken from publications sources. Therefore, in the present study, only empirical studies are utilized.

\section{Related Literature Review}

The literature presented in this section consists of several studies conducted in different sectors in Pakistan which identify the most influential factors of employee retention. Meanwhile, six sectors namely banking, education, service, manufacturing, telecom, and healthcare were examined to identify the low retention factors. The overall summary is presented in Table 1.

\section{Banking sector}

Khan et al. (2011b) found that internal service quality (job definition, work designs, selection of employee, training and development, rewards and compensation) as an important component of human resource management that influences employee retention. All these factors have a significant relationship with employee retention through job satisfaction among bank employees. Similarly, Gul et al. (2012) found that HR strategies (capacity development, employee empowerment and promotion) serve as important predictors of employee retention. When these strategies are applied, the probability of successfully retaining employees increases. This is why 
remuneration or monetary packages are more attractive to employees than other forms of packages. In line with this, Khan et al. (2011c) added compensation management as another important factor influencing job satisfaction and employee retention of bank employees. Compensation in the form of wages, incentives, rewards and other benefits given to employees boost their satisfaction level and loyalty, thus encouraging them to stay longer. Another study from the banking sector says that internal communication, training, motivation and future growth are important factors of employee retention (Ahmad et al. 2012). Masood (2013) found that work stress is a negative factor influencing employee retention in the banking sector. He added that stress could be physical, mental or behavioral. All types of stress negatively affect employees leading to issues of absenteeism, ineffectiveness, dissatisfaction and ultimately turnover. By overcoming stress, organizations can retain valuable employees. Khalid et al. (2016) added that different leadership styles influence employees in commercial banks. Transformational and transactional leadership styles help increase the satisfaction level of employees resulting in higher commitments towards the organization. Similarly, Shah and Asad (2018) found that motivation be it intrinsic or extrinsic helps organizations retain employees. Siddiqui (2018) highlighted that employee retention is influenced by strategies like work-life balance, compensation, career development, succession planning, terminal benefits and other benefits. Employees that are neglected by their organizations in these aspects are more likely to leave.

\section{Education sector}

Likewise, Saeed et al. (2013) highlighted compensation, career development and job characteristics as essential determinants of employee retention which help organizations increase the commitment level of their employees as witnessed from the education sector of Pakistan. Akhtar et al. (2015) outlined the total reward system (monetary and non-monetary benefits) as a significant predictor of employee retention among university lecturers. Further, Iqbal and Hashmi (2015) found that perceived organizational support along with psychological empowerment help educational institutions retain their employees. When employees feel that their organizations are supportive of them, they feel psychologically empowered thus creating a bond between them and their organizations which later translates into longer relationships. Tatlah et al. (2017) conducted a study on university employees and found that HR practices influence employee retention. Bibi et al. (2017) also conducted a study on employees in educational institutions in Pakistan and found that compensation, promotional opportunities and work environment are strong predictors of employee retention. In the same line, Nasir and Mahmood (2018) conducted a study on higher education employees. They found that HR practices (supervisor support, reward \& recognition, and work-life policies) contribute to employee retention. Warraich et al. (2019) in the context of library administration indicated that speedy promotions, attractive salary packages, favorable work environments, learning opportunities and development opportunities are factors that drive employees to stay. Butt rt al. (2020) found that internal marketing such as the promotion of economic values, developmental values, social values, diversity, reputational values, and organizational citizenship behavior helps organizations bring out positive employee attitude which ultimately helps in retaining them. 


\section{Service sector}

In terms of service sector organizations, Khan et al. (2011) conducted a case study on the hospitality industry in Pakistan. They found that career progression, training and development, work-life balance and job satisfaction are the main factors behind longer tenures. However, monetary rewards were found to have an insignificant relationship with employee retention. In another study, Aslam et al. (2011) indicated work conflict as the most prominent factor that negatively affects employee retention. It is found to be a significant cause for fatigue, absenteeism and low retention. Likewise, Nawaz et al. (2012) found work setting, incentives, work-life balance, career progression, colleague support, and organizational prestige as important determinants of employee retention among PIA employees. With the presence of these factors, employees become more positive and tend to stay longer. In the context of insurance employees, Ejaz and Akbar (2015) found that organizations can retain their employees by applying HR practices like training and development, compensation, performance appraisal and employee empowerment. All these factors increase the satisfaction level of employees and hence drive longer stays. Nasir and Mahmood (2016) outlined career development, supervisor support, work environment, rewards \& recognition, work-life balance and job satisfaction as the predictors of employee retention. They further categorized these predictors into three main categories namely environmental, motivational and succession planning. By testing on four different organizations, these factors were found to be strong predictors of employee retention. Sarmad et al. (2016) conducted a study on oil and gas employees and found two important predictors of employee retention i.e., compensation and motivation.

\section{Manufacturing sector}

Anis et al. (2011b), in their study on manufacturing employees found the organizational environment and training \& development as prominent factors influencing employee retention. Razaq et al. (2012) added that the most important factors affecting employee retention are remuneration and benefits, flexible environment and career development. Based on their study on employees working in the tobacco industry in Pakistan, they found that remuneration is a single breadwinner generally supports the most influential factor for employee retention over intrinsic benefits as families in Pakistan. Training and development alone are not enough without proper compensation. While training increases employee abilities, those who are unhappy with their compensation package will leave the organization when they find a more attractive option. In another study by Hussain and Rehman (2013), HR practices like training \& development, team development, performance appraisal, internal communication system, employment security, person-organization fit, reward and compensation and employee empowerment are important determinants of employee retention. These practices were found to increase the retention rate among textile employees. Ali et al. (2014) highlighted that internal marketing like motivation, empowerment, employee development and internal communication have strong impacts on manufacturing employees in leading to their retention. Internal marketing hence has a significant positive relationship with employee retention. Khalid and Nawab (2018) pointed out employee participation and compensation as important factors influencing employee retention. When 
organizations involve their employees in decision-making and provide compensation according to their needs, the employees will develop a psychological bond with the organization and tend to stay with it longer. However, participation or compensation alone is not enough to encourage them to stay.

\section{Telecom sector}

Shoaib et al. (2009) studied employee retention in the telecom industry in Pakistan. They found that career opportunities, supervisor support, working environment, rewards, and work-life policies as the basic determinants of employee retention which drive employees to stay longer. Malik et al. (2013) indicated role overload as a significant predictor of employee retention. They concluded in their study on PTCL employees that role overload is responsible for employee dissatisfaction which might contribute to employee turnover; however, if it is handled properly it can help organizations improve employee retention. Janjua dan Gulzar (2014) also found HR practices (recruitment and selection, training \& development, performance evaluation, promotion practices, compensation \& benefits and grievances handling) as important determinants of employee retention. These practices were found to increase employee commitment, loyalty and tenure. Similarly, Haider et al. (2015) also indicated HR practices i.e. training \& development, compensation, and organizational culture as significant predictors of employee retention among telecom employees.

\section{Healthcare sector}

Anis et al. (2011a) conducted a study on pharmaceutical employees and found that compensation supervisory support and organizational commitment as important elements of employee retention. Saleem and Affandi (2014) highlighted rewards and growth opportunities as important elements of employee retention with the mediating effect of perceived organizational support. Imam et al. (2018) outlined the negative effect of perceived organizational politics on employee retention. Organizational politics commonly pose a negative psychological effect on employees resulting in their insecurities and ultimately turnover. In a recent study on hospital employees, Nasir et al. (2019) indicated that employee retention is greatly influenced by career growth, remuneration, post-recognition, staff engagement and management. They also found that if gender-based differences are not eliminated, dissatisfaction will occur leading to turnover. 
Table 1: List of empirical studies from Pakistan

Sources Determinants

\begin{tabular}{|c|c|}
\hline \multicolumn{2}{|r|}{ Banks } \\
\hline Khan et al. (2011) & $\begin{array}{l}\text { Internal service quality: Employee selection, employee training and development, work design, job definition, employee rewards, } \\
\text { compensation }\end{array}$ \\
\hline Khan et al. (2011) & Compensation management, job satisfaction \\
\hline Gul et al. (2012) & Capacity development, employee empowerment, promotion \\
\hline Ahmad et al. (2012) & Internal marketing: internal communication, training, motivation, future growth \\
\hline Masood (2013) & Job stress: physical, emotional, behavioral. \\
\hline Khalid et al. (2016) & Leadership style Mediator Job satisfaction, organization commitment \\
\hline Shah and Asad (2018) & Intrinsic motivation, extrinsic motivation Mediator: Perceived organizational support. \\
\hline Siddiqui (2018) & Compensation, career development-succession progression, work-life balance, terminal / other benefits \\
\hline \multicolumn{2}{|r|}{ Education } \\
\hline Saeed et al. (2013) & Compensation, job characteristics, career development. \\
\hline Akhtar et al. (2015) & Total rewards system \\
\hline Iqbal and Hashmi (2015) & Perceived organizational support Mediator: Psychological empowerment. \\
\hline Tatlah et al. (2017) & HR practices \\
\hline Bibi et al. (2017) & Compensation, and promotional opportunities Moderator: Work environment \\
\hline Nasir and Mahmood (2018) & HR practices: Supervisor support, reward \& recognition and work-life policies \\
\hline Warraich et al. (2019) & Good salary package, conducive work environment, learning opportunities, professional development and speedy promotion. \\
\hline Butt et al. (2020) & $\begin{array}{l}\text { Internal marketing: Economic value, developmental value, social value, diversity value, reputation value, organization citizenship behavior, } \\
\text { Mediator: Favorable employee attitude }\end{array}$ \\
\hline \multicolumn{2}{|r|}{ Service } \\
\hline Aslam et al. (2011) & Work-family conflict \\
\hline Khan et al. (2011) & HR practices: Monetary rewards, career progression, training \& development, work-life balance and job satisfaction. \\
\hline Nawaz et al. (2012) & Incentive plans, work setting, supervisory support, work-life balance and organizational prestige. \\
\hline Ejaz and Akbar (2015) & HR practices: Training and development, performance appraisal, compensation, empowerment \\
\hline Nasir and Mahmood (2016) & $\begin{array}{l}\text { Supervisor support, work-life balance, career development opportunities, rewards and recognition, work environment Mediator: Job } \\
\text { satisfaction }\end{array}$ \\
\hline Sarmad et al. (2016) & Compensation, motivation \\
\hline \multicolumn{2}{|r|}{ Manufacturing } \\
\hline Anis, Nasir, et al. (2011) & Organizational environment, training and development. Mediator: Compensation \\
\hline Razaq et al. (2012) & Remuneration and benefits, flexible environment, career development. \\
\hline Hussain and Rehman (2013) & $\begin{array}{l}\text { HR practices: Training and development, development of teams, performance appraisal, internal communication system, employment } \\
\text { security, person-organization fit, employee empowerment, reward and compensation. }\end{array}$ \\
\hline Ali et al. (2014) & Internal marketing: Motivation, empowerment,_employee development, internal communication. \\
\hline Khalid and Nawab (2018) & Employee participation (direct participation, indirect participation) Moderator: Compensation \\
\hline \multicolumn{2}{|r|}{ Telecom } \\
\hline Shoaib et al. (2009) & Career opportunities, supervisor support, working environment, rewards, work-life policies. \\
\hline Malik et al. (2013) & Role overload \\
\hline
\end{tabular}


Journal of Contemporary Issues and Thought

ISSN 2232-0032/ e-ISSN 0128-0481/Vol 10, Issue 2, 2020 (36-45)

Benish Hussain (2014)

Haider et al. (2015)

Anis, Khan, et al. (2011)

Saleem and Affandi (2014)

Imam et al. (2018)

Nasir et al. (2019)
HR practices: Recruitment and selection, training and development, performance evaluation, promotion practices, compensation and social benefits, grievance handling system. Mediator: Loyalty

HR practices: Training and development, organizational culture, compensation.

\section{Healthcare}

Compensation, supervisory support, and organizational commitment

HR practices: Fairness of rewards, growth opportunities Mediator: Perceived organizational support

Perceived organizational politics, Mediator: Psychological capital

Remuneration, recognition, engagement, employee management Mediator: Gender 


\section{Conclusion and Recommendations}

The major challenge faced by organizations today is figuring how to retain valuable human resources. Therefore, the present study intends to highlight the important determinants of employee retention in the context of Pakistan. With that objective, about 35 studies have been conducted so far on employee retention involving different organizations with different predictors and strategies. Out of all these studies, only a few had been published in renowned journals. By summarizing them all, it was concluded that the most frequently studied determinants are related to human resource practices. The terminology vastly covers all HR policies and practices implemented by the organization to manage its workforce efficiently. Therefore, in light of the stated findings, it is asserted that HR practices are the most important and valuable means that influence employee retention in the context of Pakistan. These policies and practices are carried out within an economic, social, political and legal environment to utilize the workforce effectively in favor of the organization. The previous literature review had covered the banking, education, manufacturing, telecommunication and healthcare sectors. It was observed that in the context of Pakistan, literature that appropriately demonstrates the exact causes of employee retention is scarce. A majority of the empirical studies only investigated employee retention from the individual perspective while leaving out the organizational perspective.

Most of the studies did not provide any theoretical explanations except for three. Theories extracted from the studies are the social exchange theory, the Hertzberg two-factor theory and the organizational support theory. Most of the studies analyzed their data using SPSS, while only three used AMOS and another two used smart PLS. Therefore, future studies are recommended to use smart PLS and AMOS which are advanced techniques that ensure accurate results. Several industries like the retail, marketing, food and engineering sectors were completely ignored in the reviewed studies, a gap that could be addressed by future studies. This paper managed to identify future agendas that are not yet explored in highlighting the important factors of employee retention that could improve this ongoing issue in Pakistan. Furthermore, factors that were identified in the context of developed markets could be applied in the context of Pakistan in order to improve employee retention. As most of the past studies had focused on examining direct relationships, future studies can explore the use of moderating and mediating variables in examining indirect relationships instead.

\section{References}

Ahmad, N., Iqbal, N., \& Sheeraz, M. (2012). The effect of internal marketing on employee retention in Pakistani banks. International Journal of Academic Research in Business and Social Sciences, 2(8), 270-28

Akhtar, C.S., Aamir, A., Khurshid, M.A., Abro, M.M.Q., \& Hussain, J. (2015). Total rewards and retention: Case study of higher education institutions in Pakistan. Procedia-Social and Behavioral Sciences, 210(2015), 251-259.

Ali, J., Ahmed, M.A., Shaharyar, M., Haseeb, M., \& Zahoor, R. (2014). The Impact of Internal Marketing on the Employee's Retention in Sialkot Industries. International Journal of Academic Research in Business and Social Sciences, 4(9), 478-489.

Anis, A., Khan, M.A., \& Humayoun, A.A. (2011). Impact of organizational commitment on job satisfaction and employee retention in pharmaceutical industry. African Journal of Business Management, 5(17), 7316-7324. 
Anis, A., Nasir, A., \& Safwan, N. (2011). Employee retention relationship to training and development: A compensation perspective. African journal of business management, 5(7), 26-79.

Aslam, R., Shumaila, S., Azhar, M., \& Sadaqat, S. (2011). Work-family conflicts: Relationship between work-life conflict and employee retention-A comparative study of public and private sector employees. Interdisciplinary Journal of Research in Business, 1(2), 18-29.

Bibi, P., Pangil, F., Johari, J., \& Ahmad, A. (2017). The Impact of Compensation and Promotional Opportunities on Employee Retention in Academic Institutions: The Moderating Role of Work Environment. International Journal of Economic Perspectives, 11(1), 378-391.

Butt, A., Lodhi, R.N., \& Shahzad, M.K. (2020). Staff retention: a factor of sustainable competitive advantage in the higher education sector of Pakistan. Studies in Higher Education, 1-21. $10.1080 / 03075079.2019 .1711038$

Ejaz, S., \& Akbar, W. (2015). An effectiveness of human resource management practices on employee retention findings from insurance companies of Karachi. European Journal of Business and Management, 7(7), 2733.

Ghulam, W.A., Ali, W., Ali, S., Khan, M.M., Khan, R.N.A., \& Farooq, M. (2019). Investigating Factors Influencing Brain Drain of Citizens of Azad Kashmir Pakistan. The Journal of Social Sciences Research, 5(3), 782-788.

Gul, A., Akbar, S., \& Jan, Z. (2012). Role of Capacity Development, Employee empowerment and Promotion on Employee Retention in the banking sector of Pakistan. International Journal of Academic Research in Business and Social Sciences, 2(9), 284-300.

Haider, M., Rasli, A., Akhtar, C.S., Yusoff, R.B.M., Malik, O.M., Aamir, A., ... \& Tariq, F. (2015). The impact of human resource practices on employee retention in the telecom sector. International Journal of Economics and Financial Issues, 5(1S), 63-69.

Hussain, T., \& Rehman, S.S. (2013). Do human resource management practices inspire employees' retention. Research Journal of Applied Sciences, Engineering and Technology, 6(19), 3625-3633.

Imam, T., Ali, H., \& Soo, H.S. (2018). Dilemma of Employee Retention through the Lens of Organizational Politics: A Quantitative Study on Pharmaceutical Industry of Pakistan. International Journal of Academic Research in Accounting, Finance and Management Sciences, 8(3), 26-36.

Iqbal, S., \& Hashmi, M.S. (2015). Impact of perceived organizational support on employee retention with mediating role of psychological empowerment. Pakistan Journal of Commerce and Social Sciences (PJCSS), 9(1), 1834.

Iqbal, S., Guohao, L., \& Akhtar, S. (2017). Effects of job organizational culture, benefits, salary on job satisfaction ultimately affecting employee retention. Review of Public Administration and Management, 5(3), 1-7.

Janjua, B.H., \& Gulzar, A. (2014). The impact of human resource practices on employee commitment and employee retention in telecom sector of Pakistan: Exploring the mediating role of employee loyalty. IOSR Journal of Business and Management, 16(1), 76-81.

Khalid, K., \& Nawab, S. (2018). Employee participation and employee retention in view of compensation. SAGE Open, 8(4), 1-7.

Khalid, N., Pahi, M.H., \& Ahmed, U. (2016). Loosing your best talent: Can leadership retain employees? The dilemma of the banking sector of Hyderabad Sindh, Pakistan: A mediation investigation. International Review of Management and Marketing, 6(3), 608-616.

Khan, A.A., Mahmood, B., Ayoub, M., \& Hussain, S. (2011). An empirical study of retention issues in hotel industry: A case study of Serena Hotel, Faisalabad, Pakistan. European Journal of Economics, Finance and Administrative Sciences, 1(29), 7-18.

Khan, M.A., \& Ahmad, N.S.A. (2011). Modeling link between internal service quality in human resources management and employees retention: A case of Pakistani privatized and public sector banks. African Journal of Business Management, 5(3), 949-959.

Khan, R.I., Aslam, H.D., \& Lodhi, I. (2011). Compensation Management: A strategic conduit towards achieving employee retention and Job Satisfaction in Banking Sector of Pakistan. International journal of human resource studies, 1(1), 89-97.

Malik, M.I., Sajjad, M., Hyder, S., Ahmad, M.S., Ahmed, J., \& Hussain, S. (2013). Role overload: A cause of diminishing employee retention and productivity. Middle-East Journal of Scientific Research, 18(11), 15731577.

Masood, A. (2013). Effects of job stress on employee retention: a study on banking sector of Pakistan. International Journal of Scientific and Research Publications, 3(9), 1-8. 
Najib, M., Abdullah, S., Narresh, S., \& Juni, M. H. (2019). Brain-drain phenomenon among healthcare workers. International Journal of Public Health and Clinical Sciences, 6(3), 90-103.

Nasir, F., Ashraf, M., \& Riaz, M. (2019). The Role of Gender in Employee Retention: A Study of Private Hospitals in Karachi. International Journal of Experiential Learning \& Case Studies, 4(1), 157-171.

Nasir, S.Z., \& Mahmood, N. (2016). Determinants of employee retention: An evidence from Pakistan. International Journal of Academic Research in Business and Social Sciences, 6(9), 182-194.

Nasir, S.Z., \& Mahmood, N. (2018). A Study of Effect of Employee Retention on Organizational Competence. International Journal of Academic Research in Business and Social Sciences, 8(4), 408-415.

Nawaz, N., Jahanian, A., \& Tehreem, S. (2012). Determinants of employee retention in Pakistan International Airlines (PIA). European Journal of Business and Management, 4(7), 45-53.

Razaq, A., Sabir, M., \& Hameed, R.M. (2012). Retention of adept employees: Preliminary study on PTC-Pakistan. Journal of Business and Management, 3(5), 13-16.

Saeed, R., Nayyab, H.H., Lodhi, R.N., Baqir, R., Rehman, M.A., \& Mussawar, S. (2013). Impact of retention factors on organizational commitment in general education division of Pakistan. Middle-East Journal of Scientific Research, 17(4), 539-545.

Saleem, M., \& Affandi, H. (2014). HR Practices and Employees Retention, an empirical analysis of Pharmaceutical sector of Pakistan. IOSR Journal of Business and Management, 16(6), 111-116.

Sarmad, M., Ajmal, M.M., Shamim, M., Saleh, M., \& Malik, A. (2016). Motivation and Compensation as Predictors of Employees' Retention: Evidence From Public Sector Oil and Gas Selling Organizations. Journal of Behavioural Sciences, 26(2), 174-188.

Shah, M., \& Asad, M. (2018). Effect of motivation on employee retention: Mediating role of perceived organizational support. European Online Journal of Natural and Social Sciences, 7(2), 511-520.

Shoaib, M., Noor, A., Tirmizi, S.R., \& Bashir, S. (2009). Determinants of employee retention in telecom sector of Pakistan. Proceedings of the 2nd CBRC, Lahore, Pakistan, 14, 1-18.

Siddiqui, F. (2018). Impact of Retention Strategies on Employee Turnover: A Case in Point. Journal of Resources Development and Management, 42(1), 1-10.

Tatlah, I.A., Anwar, M., \& Amin, M. (2017). Effect of Human Resource Practices on Employees' Retention in a Private University of Pakistan. Journal of Educational Research (1027-9776), 20(1), 100-112.

Warraich, N.F., Ameen, K., \& Malik, A. (2019). Recruitment and retention of information professionals: library leaders' perspectives in Pakistan. Global Knowledge, Memory and Communication. 10.1108/GKMC-012019-0003 